UNDERGRADUATE RESEARCH IN NATURAL AND CLINICAL SCIENCE AND TECHNOLOGY (URNCST) JOURNAL Read more URNCST Journal articles and submit your own today at: https://www.urncst.com

\title{
Investigating the Effect of $\Delta 9$-tetrahydrocannabinol on Brain-Derived Neurotropic Factor Levels in Depressed Male Rats
}

\author{
Jenan Bouakkar, HBSc Student [1], Hafsah A. Sheikh, HBSc Student [1]*, \\ Sebastian Dowhanik, HBSc Student [1], Said Aoude, HBSc Student [1] \\ [1] Department of Biological Sciences, University of Toronto, Toronto, Ontario, Canada \\ *Corresponding Author: hafsah.sheikh@mail.utoronto.ca
}

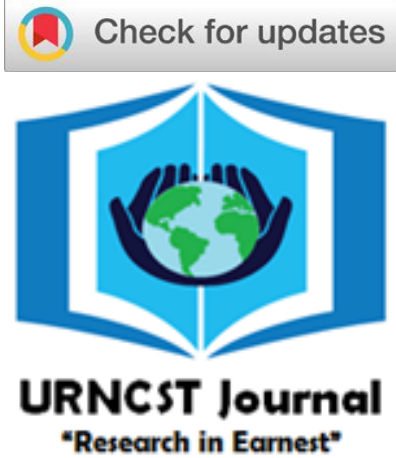

\begin{abstract}
Introduction: Despite the legalization of cannabis in Canada, researchers have yet to understand the extent of its side effects on neural development. This is especially true when considering the impact of cannabis on those with mental illnesses including depression. One vital protein involved in the growth and differentiation of neurons in the brain is the brain-derived neurotrophic factor (BDNF). The aim of our proposed study is to evaluate how the neural health of depressed individuals is impacted by $\Delta 9$-tetrahydrocannabinol (THC) consumption, the primary psychoactive component of cannabis, in comparison to those without depression by comparing their respective BDNF levels.

Methods: To test this, we will use olfactory bulbectomised rats as models for depression and measure the BDNF concentration in their frontal cortices, hippocampi, and amygdalae following controlled exposure to THC for 21 days via intraperitoneal injections. BDNF will be detected via Western blot and quantified using BDNF-specific ELISAs.

Conclusion: Our study could influence how society views the risks associated with the use of cannabis amongst individuals with depression. Given that BDNF baseline levels are lower in individuals with depression versus those without, the potentially significant effect of BDNF on overall neural development could possibly be impacted by recurrent THC dosages. Our study could impact the frequency of usage of THC amongst depressed individuals.
\end{abstract}

Keywords: amygdala; bdnf; bilateral olfactory bulbectomy surgery; cannabis; depression; hippocampus; THC

\section{Introduction}

On October 17, 2018, the Canadian government legalized the purchase and use of recreational cannabis by individuals 19 or older [1]. However, studies have shown that cannabis has an effect on the long-term memory and adolescent brain development of both rodents and humans [2-4]. Nevertheless, there have been insufficient studies investigating the effect cannabis has on the brain development of people with depression [5]. This is concerning since up to one-third of individuals aged 18-24 have reported using cannabis and they also have the highest prevalence of major depressive episodes [6]. Therefore, it is important we focus on understanding how cannabis affects the brain development and cognitive ability of those suffering from mental illnesses [6, 7].

When studying cannabis' effect on the brain, researchers focus on its main psychoactive component, $\Delta$ 9-tetrahydrocannabinol (THC). Segal-Gavish et al. showed that schizophrenic mice produced less brainderived neurotrophic factor (BDNF) following THC administration compared to wild-type (WT) [8]. BDNF is a neurotrophic protein that acts on the central nervous system to support the development and maintenance of neurons and synapses [9]. BDNF is principally active in the basal forebrain and hippocampus, and is thought to be vital for long-term memory and maintaining normal neural development. Its overexpression partially counteracts the harmful effects of THC on the brain $[8,10]$. We want to test how strongly depressed rats can counteract the negative effects of cannabis, compared to WT, by measuring BDNF levels in the hippocampus and amygdala of WT and depressed rats after THC administration. According to previous studies, depression in rats can be modelled by conducting olfactory bulbectomy, or a surgical removal of the olfactory bulbs $[11,12]$. Hence, we shall use that model to induce depression. We hypothesize that male adolescent rats with induced depression will have a lower surge in BDNF levels upon THC exposure in comparison to WT rats, based on previous studies which seem to indicate less pronounced changes in BDNF levels in depressed rats when exposed to THC [11].

\section{Methods}

Before the experiment, a population of 100 healthy male adolescent rats, 42 to 51 days postnatal, will be kept at room temperature $\left(22 \pm 2^{\circ} \mathrm{C}\right)$ and given ample food and water for a week to allow them to acclimatize to the laboratory environment. Males were chosen because 
UNDERGRADUATE RESEARCH IN NATURAL AND CLINICAL SCIENCE AND TECHNOLOGY (URNCST) JOURNAL Read more URNCST Journal articles and submit your own today at: https://www.urncst.com

literature indicates pronounced neurological effects of cannabis use among male adolescents [13]. The rats will be weighed daily between 9:00 A.M. and 9:30 A.M., and only those $180 \mathrm{~g}$ to $300 \mathrm{~g}$ will be used for the study in accordance with ElBatsh et al. [11]. Half of the remaining rats will be selected to receive the bilateral olfactory bulbectomy (OB), identical to that conducted by ElBatsh et al., to induce depression [12]. The remaining half will be subjected to a sham surgery involving the same drilling procedure but without olfactory bulb removal. The rats will be given two weeks to recover, during which time they will be weighed daily between 9:00 A.M. and 9:30 A.M. [11]. This weighing process shall be repeated after THC administration begins to compare their growth.

The bulbectomised $(\mathrm{OB})$ rats will be subjected to an open field test on a circular arena, as performed by ElBatsh et al., to determine their level of neophobia (fear of new or unfamiliar surroundings) after surgery [12]. The manifestation of neophobia will be an indicator of depression, and therefore, an indicator of a successful OB surgery [12]. Those not manifesting neophobia will be excluded from the study. The $\mathrm{OB}$ and WT rats will each be further divided into 2 groups: those receiving $\mathrm{THC}$ and those that are not. Those receiving THC will be injected intraperitoneally with a $2.0 \mathrm{mg} / \mathrm{kg}$ dose of THC every 48 hours, in accordance with Elbatsh et al. [11]. Intraperitoneal injections would permit us to control the amount of $\mathrm{THC}$ the rats are exposed to. The rats not receiving $\mathrm{THC}$ will receive a $1.0 \mathrm{mg} / \mathrm{kg}$ vehicle treatment (of cremophor, ethanol, and saline in a ratio of 1:1:18 respectively) intraperitoneally every 48 hours, serving as a negative control [11]. These THC and vehicle doses will be administered to the rats for a period of 21 days (Figure 1).

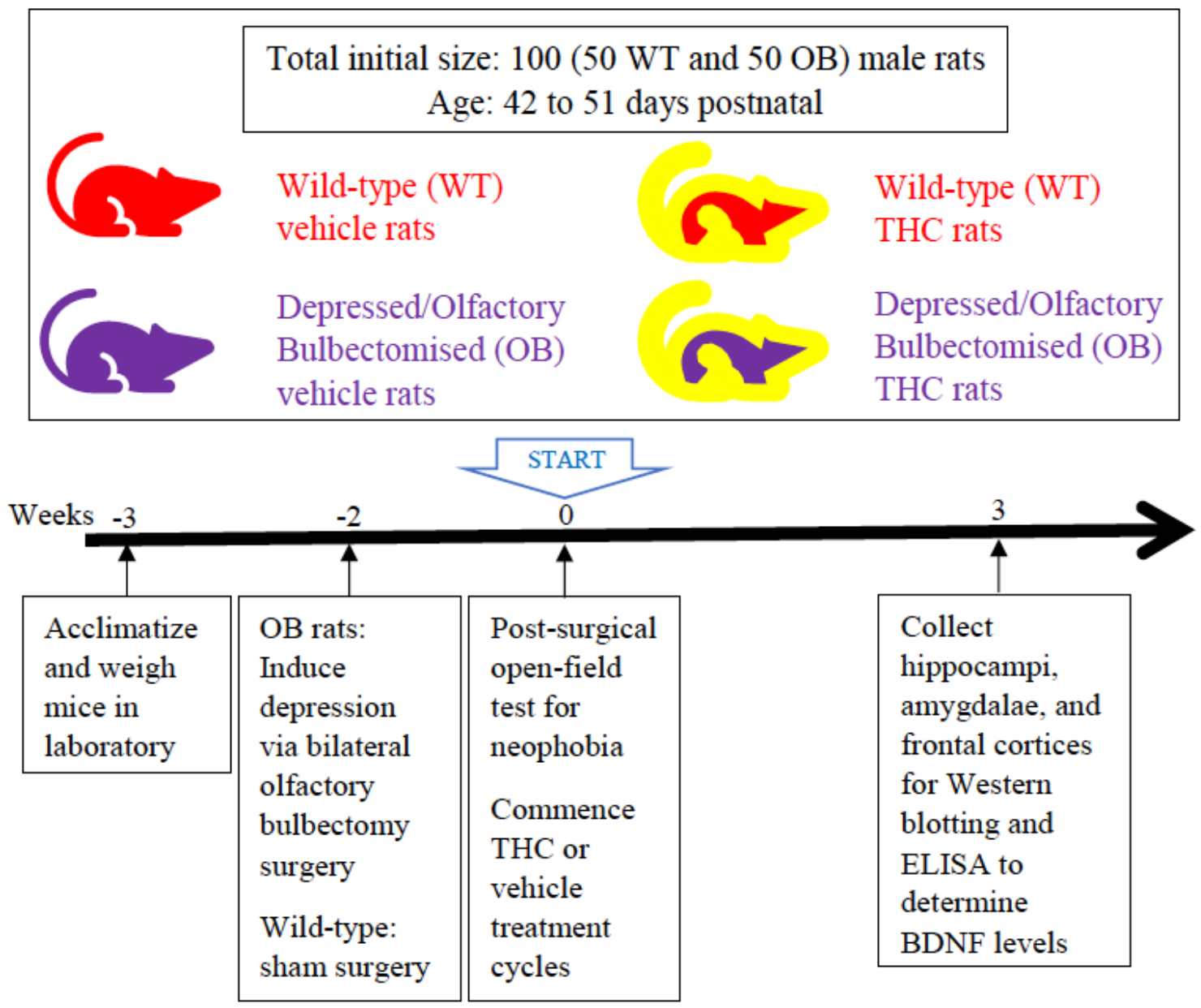

Figure 1: Overview of the experiment. Week 0 marks the start of THC and vehicle administration. After three weeks of treatment, BDNF level data collection begins. 
UNDERGRADUATE RESEARCH IN NATURAL AND CLINICAL SCIENCE AND TECHNOLOGY (URNCST) JOURNAL Read more URNCST Journal articles and submit your own today at: https://www.urncst.com

\section{Results}

After the 21 days, BDNF levels of each rat exhibiting neophobia will be analyzed by extracting the hippocampi, frontal cortices, and the amygdalae. These will be dissected and stored at $-80^{\circ} \mathrm{C}$. The proteins in the hippocampus and amygdala will be evaluated via Western blot and a BDNF-specific ELISA kit to detect and quantify the presence of BDNF. For the primary antibody in the Western blot, anti-BDNF antibody in blocking solution will be used. We anticipate a surge in BDNF levels after the administration of THC. This surge would be greater in WT rats as opposed to the depressed ones, representing how effectively BDNF counteracts the negative effects of THC.

\section{Discussion}

The results will be used to compare between the WTTHC (non-depressed rats) and the OB-THC (bulbectomized/depressed rats) groups. The controls are represented by the WT-Vehicle and the OB-Vehicle groups which help us control for the baseline BDNF content in the OB and WT groups without the influence of THC. Statistical significance can be evaluated via a twoway ANOVA and a Tukey's post-hoc test, with significance set to $p<0.05$. As with any study, there are a few limitations to consider. In our case, although BDNF is an extremely vital factor in promoting the healthy development of neurons and synapses, its concentration in the brain is not the sole measure of a cognitive function or long-term memory. For instance, TrkB receptors (to which BDNF binds) and thyroid hormone receptors are both very important in terms of promoting brain $[14,15]$. Furthermore, the OB rats to be used in this study are not perfect models for depression in humans [16]. So, these rats may not necessarily be affected by THC in the same manner as humans with depression.

\section{Conclusions}

Our results may shed light on the detrimental effects of THC on neural development in individuals suffering from mental illnesses like depression who often resort to marijuana consumption as part of recreational/therapeutic use. Following the legalisation of cannabis in Canada, this can help educate Canadians and marijuana consumers regarding the harms of $\mathrm{THC}$ on aspects like brain development and long-term memory, particularly on depressed adolescents. BDNF is an essential component of the brain development process. It manifests higher baseline levels when exposed to THC as a negative feedback response. These BDNF surges are expected to be lower in individuals with depression versus those without; thus, suggesting that constant THC exposure to depressed individuals increases the risk of cognitive deficiencies. Our study could impact the frequency of usage of THC amongst individuals with depression.

\section{List of Abbreviations}

Brain-derived neurotrophic factor (BDNF): A growth factor of the neurotrophic family encoded by the BDNF gene that is found in the hippocampus, cortex, and basal forebrain.

Enzyme-Linked Immunosorbent Assay (ELISA): An assay method used for detecting and quantifying the presence of a ligand (hormone, protein, antibodies, etc.) using a ligand-specific antibody linked to an enzyme that generates a measurable product.

Olfactory Bulbectomy (OB): A surgery involving the removal of the olfactory bulbs. Commonly used to induce depression in rat models.

49-tetrahydrocannabinol (THC): A cannabinoid that is classified as the main psychoactive component of cannabis.

\section{Conflicts of Interest}

The author(s) declare that they have no conflict of interests.

\section{Ethics Approval and/or Participant Consent}

All article types: This proposal did not require ethics approval, as it was a protocol designed for a case competition.

\section{Authors' Contributions}

SD: made contributions to the design of the study, drafted the manuscript, and gave final approval of the version to be published.

HAS: contributed to study design and planning, drafted the manuscript, and gave final approval of the version to be published.

JB: contributed to the design of the study, revised the manuscript critically, and gave final approval of the version to be published.

SA: contributed to the design of the study, revised the manuscript critically, and gave final approval of the version to be published.

\section{Acknowledgements}

We would like to thank and acknowledge the support provided by the University of Toronto Scarborough Scinapse Club in composing this proposal.

\section{Funding}

This study was not funded.

\section{References}

[1] Vogt, NA, Sargeant, JM, Stevens, CPG, \& Dunn, JN. A survey of veterinary student attitudes concerning whether marijuana could have therapeutic value for animals. PLoS One. $2019 \mathrm{Jul} ; 14(7)$. https://doi.org/10.1371/ journal.pone. 0219430 
UNDERGRADUATE RESEARCH IN NATURAL AND CLINICAL SCIENCE AND TECHNOLOGY (URNCST) JOURNAL Read more URNCST Journal articles and submit your own today at: https://www.urncst.com

[2] Chen, C-Y, Wagner, FA, \& Anthony, JC. Marijuana use and the risk of Major Depressive Episode: Epidemiological evidence from the United States National Comorbidity Survey. Social Psychiatry and Psychiatric Epidemiology. 2002 May; 37(5): 199-206. https://doi.org/10.1007/s00127-002-0541-z

[3] Ilan, AB, Smith, ME, \& Gevins, A. Effects of marijuana on neurophysiological signals of working and episodic memory.

Psychopharmacology. 2004 Nov;176(2): 214-222. https://doi.org/10.1007/s00213-004-1868-9

[4] Jacobus, J \& Tapert, SF. Effects of cannabis on the Adolescent Brain. Current Pharmaceutical Design. 2014;20(13): 2186-2193. https://doi.org/10.2174/13816128113199990426

[5] Boyce, A, \& McArdle, P. Long-term effects of cannabis. Paediatrics and Child Health. 2008 Jan; 18(1): 37-41. https://doi.org/10.1016/j.paed.2007.10.006

[6] Rotermann, M \& Langlois, K. Prevalence and correlates of marijuana use in Canada, 2012. Health Reports. 2015 Apr 15;26(4): 8.

[7] National Institute of Mental Health. Major Depression [2018 Nov 22]. Available from https://www.nimh.nih.gov/health/statistics/majordepression.shtml

[8] Segal-Gavish, H, Gazit, N, Barhum, Y, Ben-Zur, T, Taler, M, Hornfeld, SH, Gil-Ad, I, Weizman, A, Slutsky, I, Niwa, M, Kamiya, A, Sawa, A, Offen, D, Barzilay, R. BDNF overexpression prevents cognitive deficit elicited by adolescent cannabis exposure and host susceptibility interaction. Human Molecular Genetics. 2017 Apr 11;26(13): 2462-2471. https://doi.org/10.1093/hmg/ddx139

[9] Huang, EJ, \& Reichardt, LF. Neurotrophins: Roles in Neuronal Development and Function. Annual Review of Neuroscience. 2001;24: 677-736. https://doi.org/10.1146/annurev.neuro.24.1.677

[10] Ernfors, P, Lee, K \& Jaenisch, R. Mice lacking brain-derived neurotrophic factor develop with sensory deficits. Nature. 1994 Mar 10;368: 147-150. http://doi.org/10.1038/368147a0

[11] ElBatsh, MM, Moklas, MAA, Marsden, CA \& Kendall, DA. Antidepressant-like effects of $\Delta 9$-tetrahydrocannabinol and rimonabant in the olfactory bulbectomised rat model of depression. Pharmacology Biochemistry and Behavior. 2012 Aug;102(2): 357-365. https://doi.org/10.1016/j.pbb.2012.05.009
[12] Morales-Medina, JC., Iannitti, T, Freeman, A, \& Caldwell, HK. The olfactory bulbectomized rat as a model of depression: The hippocampal pathway. Behavioural Brain Research. 2017 Jan; 317: 562-575. http://doi.org/10.1016/j.bbr.2016.09.029

[13] French, L, Gray, C, Leonard, G, Perron, M, Pike, GB, Richer, L, Séguin, JR, Veillette, S, Evans, CJ, Artiges, E, Banaschewski, T, Bokde, AW, Bromberg, U, Bruehl, R, Buchel, C, Cattrell, A, Conrod, PJ, Flor, H, Frouin, V, Gallinat, J, Garavan, H, Gowland, P, Heinz, A, Lemaitre, H, Martinot, JL, Nees, F, Orfanos, DP, Pangelinan, MM, Poustka, L, Rietschel, M, Smolka, MN, Walter, H, Whelan, R, Timpson, NJ, Schumann, G, Smith, GD, Pausova, Z, \& Paus, T (2015). Early cannabis Use, Polygenic Risk Score for Schizophrenia and Brain Maturation in Adolescence. JAMA psychiatry. 2015 Oct;72(10): 1002-1011. http://doi.org/10.1001/ jamapsychiatry.2015.1131

[14] Bernal, J. Thyroid hormone receptors in brain development and function. Nature Reviews Endocrinology. 2007 Mar;3(3): 249-259. https://doi.org/10.1038/ncpendmet0424

[15] Mizuno, M, Yamada, K, He, J, Nakajima, A, \& Nabeshima, T. Involvement of BDNF Receptor TrkB in Spatial Memory Formation. Learning \& Memory. 2003;10(2): 108-115. https://doi.org/10.1101/1m.56003

[16] Yurttas, C, Schmitz, C, Turgut, M, Strekalova, T, $\&$ Steinbusch, HWM. The olfactory bulbectomized rat model is not an appropriate model for studying depression based on morphological/stereological studies of the hippocampus. Brain Research Bulletin. 2017 Sept;134: 128-135. https://doi.org/10.1016/j.brainresbull.2017.07.010

[17] Binder, DK \& Scharfman, HE. Brain-derived Neurotrophic Factor. Growth Factors. 2004 Sept; 22(3): 123-131. https://doi.org/10.1080/08977190410001723308

[18] Gan, SD, \& Patel, KR (2013). Enzyme immunoassay and enzyme-linked immunosorbent assay. The Journal of Investigative Dermatology. 2013 Sept;133(9): 1-3. https://doi.org/10.1038/jid.2013.287

[19] Pate, DW. Possible role of ultraviolet radiation in evolution of Cannabis chemotypes. Economic Botany. 1983 Oct;37(4): 396-405. https://doi.org/10.1007/BF02904200 
UNDERGRADUATE RESEARCH IN NATURAL AND CLINICAL SCIENCE AND TECHNOLOGY (URNCST) JOURNAL Read more URNCST Journal articles and submit your own today at: https://www.urncst.com

Article Information

Managing Editor: Jeremy Y. Ng

Peer Reviewers: Bi-Ru Amy Yeung, Jennifer Williams, Vinay Patel

Article Dates: Received Nov 18 19; Accepted Jan 17 20; Published Feb 1020

\section{Citation}

Bouakkar J, Sheikh HA, Dowhanik S, Aoude S. Investigating the effect of $\Delta 9$-tetrahydrocannabinol on brain-derived neurotropic factor levels in depressed male rats. URNCST Journal. 2020 Feb 10: 4(2). https://urncst.com/index.php/urncst/article/view/173

DOI Link: https://doi.org/10.26685/urncst.173

\section{Copyright}

(C) Jenan Bouakkar, Hafsah A. Sheikh, Sebastian Dowhanik, Said Aoude (2020). Published first in the Undergraduate Research in Natural and Clinical Science and Technology (URNCST) Journal. This is an open access article distributed under the terms of the Creative Commons Attribution License (https://creativecommons.org/licenses/by/4.0/), which permits unrestricted use, distribution, and reproduction in any medium, provided the original work, first published in the Undergraduate Research in Natural and Clinical Science and Technology (URNCST) Journal, is properly cited. The complete bibliographic information, a link to the original publication on http://www.urncst.com, as well as this copyright and license information must be included.

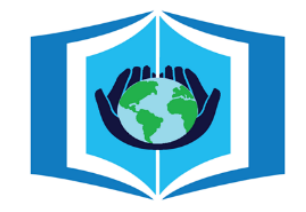

\section{URNCST Journal \\ "Research in Earnest"}

\section{Funded by the \\ Government of Canada}

\section{Canadà}

Do you research in earnest? Submit your next undergraduate research article to the URNCST Journal!

| Open Access | Peer-Reviewed | Rapid Turnaround Time | International |

| Broad and Multidisciplinary | Indexed | Innovative | Social Media Promoted |

Pre-submission inquiries? Send us an email at info@urncst.com | Facebook, Twitter and LinkedIn: @URNCST

Submit YOUR manuscript today at https://www.urncst.com! 